\title{
MANAGING THE EQUILIBRIUM BETWEEN ECONOMIC DEVELOPMENT, NATIONAL SECURITY AND CAPITALISM
}

\section{Florina BRAN ${ }^{a^{*}}$, Dumitru Alexandru BODISLAV ${ }^{b}$, Raluca Iuliana GEORGESCU $^{c}$, Svetlana PLATAGEA GOMBOȘ ${ }^{d}$}

${ }^{a, b, c, d}$ Bucharest University of Economic Studies, Romania

\begin{abstract}
This paper analyses the relation and developed equilibrium between economic development, national security and capitalism by evaluating the fields of foreign policy, national security and strategic partnerships. The purpose is to offer a global perspective on Romania's vantage point towards globalization.
\end{abstract}

KEYWORDS: economic development, foreign policy, national security.

DOI: 10.24818/IMC/2021/01.20

\section{INTRODUCTION}

At the moment, there is agreement on the importance of protecting producers' property rights in order to achieve long-term economic progress (Acemoglu, Johnson, Robinson, 2001, pp. 13691401). There is no consensus on the phenomena of producer property rights protection or the advantages of enhancing the legal and economic environment for any type of property rights (Radulescu et al. 2020). The oligarchic society is taking shape, with the "economic elite" (large producers and investors in the economy) wielding political power (Bodislav et al., 2020). The form of interest group organization maintains the domination of large producers, which is reflected by low taxation but also by inefficiencies based on the development of monopoly positions for them, thereby infringing on future property rights of potential producers (Negescu Oancea, et al., 2020). The alternative is democracy, in which political power is distributed fairly, resulting in a linearization of budget revenues through a stepped tax on revenues; instead, large producers will not erect barriers to entry for new producers, preserving the concept of potential producer ownership; however, what happens if the democratic and oligarc systems merge? This approach introduces two distortions into the state's economic policy: taxonomy and entry restrictions (Acemoglu, 2008, pp. 1-41). Taxes that redistribute revenue from businesses to workers distort the market because they deter investment (Bran et al., 2018). Barriers to entry distort resource allocation because they might prevent the entry of other potentially more productive economic agents, redistributing wealth to the entrepreneur by lowering labor demand and wages (Jianu et al., 2019).

The trade between the two sorts of distortions decides whether the oligarchy or democracy is more efficient and produces more aggregate output (Ionita et al., 2009). The oligarchy is immune to the negative impacts of taxation, but it is subject to the distortions caused by the installation of entry barriers. Higher taxes are imposed by democracy, but it also creates a "fair playing field" (without barriers to entry). The oligarchy becomes the efficient model and generates greater output when the taxes imposed in a democracy are high and the distortions caused by barriers to entry are low; when the "democratic taxonomy" is low and with barriers to entry that create an inefficient allocation of

\footnotetext{
* Corresponding author. E-mail address: florinabran@yahoo.com
} 
resources, a higher aggregate output is eventually obtained . Furthermore, a democratic society has a more equal distribution of income than an oligarchic society because it redistributes money from entrepreneurs to workers, whereas an oligarchic society implements policies that reduce labor demand, cut salaries, and enhance the profits of entrepreneurs.

\section{BENEFITS OF MODERN DEMOCRACIES}

The interchange between the two sorts of distortions decides whether the oligarchy or democracy is more efficient and produces more aggregate production. The oligarchy is immune to the negative impacts of taxes, but it is subject to the distortions caused by the creation of entry barriers. Higher taxes are imposed by democracy, but it also creates a "fair playing field" (without barriers to entry). The oligarchy becomes the efficient model and generates greater output when the taxes imposed in a democracy are high and the distortions caused by barriers to entry are low; when the "democratic taxonomy" is low and with barriers to entry that create an inefficient allocation of resources, a higher aggregate output is eventually obtained. A democratic society also creates a more equal distribution of income than an oligarchic society because it redistributes money from entrepreneurs to workers, whereas an oligarchic society implements policies that reduce labor demand, cut salaries, and enhance the profits of entrepreneurs.

The dynamics of the interaction between the two political systems are fascinating (political, but with purely economic goals). Initially, the entrepreneurs will be the ones with better output, making the fact that they are no longer members of the working class, but of the producing class effective, limiting the distortions caused by the oligarchic society. However, the advantage that establishes the company erodes over time, and the manufacturer entering the market will lose it, but the oligarchy's obstacles to entry will keep the firm going even if the advantage (core business idea) has been lost (Georgescu, 2020). Between the two types of societies, an algorithm can be seen: although they appear to be identical at first, the oligarchy will quickly become wealthy, but in the long run will have less wealth than the democratic society; thus, the model suggests that democracy is more economically efficient in the long run than the alternative, despite the economic distortions (Burlacu, 2011). Democracy, rather than oligarchic society, has the potential to gain more from emerging technology (Pricop et al., 2016). This is due to the fact that democracy gives agents a competitive edge over technology that can be applied entrepreneurially, but the oligarchy prevents such implementations. Thus, a society's political system and political power distribution reveal whether it is oligarchic or democratic. Is it possible for a society to be oligarchic even if the regime's upkeep is expensive? Social groups who have become wealthy as a result of a political system will defend and support that regime. The large producers already have political influence under the oligarchic system, and they manage entrance barriers with a single aim in mind: enormous profit. Even if entrance restrictions are ineffectual, these large earnings are directly proportionate to political power, making the shift from oligarchy to democracy difficult.

\subsection{A view on the Romanian situation}

As a supporter of national interests, a member of NATO, and an active participant in the European Union, the Romanian state must promote and safeguard democracy and human rights. It must be carried out in tandem with international legal norms for modernization, economic and social growth, as well as the expression of national identity.

Failures in the fields of international affairs and national security are unacceptable since they can have significant implications for citizens' quality of life, as well as the loss of the country's or certain regions' autonomy. In comparison to states that did not experience the communist era, national security is regarded as a public good in Western countries, with the safety and efficiency of 
security forces being prioritized over the quality of citizens' daily lives; this means that national security policy is a public policy.

The development, identification, and admittance of such a policy in Western nations is done using an algorithm known as the "Western acquis of security policy."

\section{FOREIGN POLICY EXPANDED}

Regarding the Romanian state, foreign policy is the main means of promoting national values and interests internationally. The foreign policy of our country will be focused on the following directions:

- Development of cooperation with EU states through regional and cross-border cooperation projects;

- Participation in the process of concretizing the European security and defense policy;

- Major interest in improving the legal status and solving the problems of minorities in other states;

- Providing support in order to preserve the national and cultural identity of national communities outside Romania;

- Supporting UN operations that promote regional and global peace and trust.

\subsection{Common Foreign and Security Policy (CFSP)}

The common foreign and security policy introduced following the Maastricht Treaty in 1992 and improved by the Amsterdam and Nice Treaties is subject to the application of special rules and procedures. The CFSP is defined and implemented by the European Council and the High Representative of the Union for Foreign Affairs and Security Policy.

The CFSP is based on developing mutual political solidarity between states, identifying issues of general interest and achieving a high degree of convergence between Member States. They shall therefore refrain from any action which is contrary to the interests of the Union or which could harm its effectiveness as a cohesive force.

CFSP instruments include:

1. Decisions - are common positions in a specific file, or joint actions that make it possible to mobilize material and financial resources;

2. Statements - public positions on specific current issues;

3. Written or verbal approaches - made to generate a conduct or action;

4. Political dialogue - is a means of promoting CFSP objectives;

5. Restrictive measures - adopted in response to violations of international human law or democratic principles are applied in accordance with the legal provisions of treaties or UN Security Council resolutions;

6. Joint operations.

For Romania, the Common Foreign and Security Policy is an essential landmark in designing the national vision on regional security. Romania has been active in supporting the CFSP, even before joining the EU, all the while pursuing with priority the valorization of our position as a border state.

\subsection{The strategic partnership with the US}

The Ministry of Foreign Affairs (MFA) continues to develop and expand its strategic partnership with the United States, one of the fundamental pillars of foreign policy in our country. The Ministry contributed to the achievement of the main objectives in this relationship with the help of an intensification of the politico-diplomatic dialogue of achieving a significant level of trade and the need for the transatlantic relationship. 
Beyond the politico-military component, Romania will act on other areas, first of all the economic and investment one. There is an increase in US investment in the Romanian market, wanting this trend to continue. Also of priority interest is energy cooperation with a focus on civilian nuclear energy, the completion of regional energy projects and the exploitation of Black Sea gas reserves.

As part of the same security and values community, Romania will remain in multilateral formats, including NATO and the EU, a promoter of the transatlantic relationship, being particularly important.

Following the common vision of this partnership, the following areas of collaboration are pursued:

1. Combating terrorism and eliminating other risks and threats by strengthening the exchange of information;

2. Cooperation within NATO;

3. Trade and investment, including by facilitating contacts between business communities together with a commitment to market principles, the rule of law, a healthy business environment, transparency and public integrity;

4. Education, research and interpersonal contacts, through the exchange of staff from various backgrounds.

\subsection{The strategic partnership with Japan}

Japan is the second largest economic power in Asia and the third largest in the world. The relationship between Romania and Japan has been formed in the last hundred years and it has been based on the communion of values and the convergence of interests in global issues, on mutual respect manifested during a century of political and international transformations.

Japan is one of Romania's main Asian economic partners; massively supported with financial and technical assistance the Romanian reform process. Loans were granted for the rehabilitation of parts of national roads and railways, the modernization of a thermal power plant, a part of the port

\section{ANALYSIS OF FOREIGN POLICY}

National security is the fundamental condition for the existence of the Romanian nation and state, which has as its field of reference national values, interests and needs.

As public order is at the heart of the interests of the state and the citizen, this area is an important component of national security. Its actions aim at preventing and combating crime, as well as protecting citizens.

Directions of action of public order and safety:

1. Legislative harmonization;

2. Partnerships with similar structures from other EU member states;

3. Securing the state border;

4. Protection of the right to privacy;

5. Fight against terrorism, corruption and organized crime;

6. Restructuring the institutional system of public order.

The main guarantor of our country's security is the NATO Alliance. Romania must act to continue the reform of the army, in accordance with the standards of NATO and EU member states, to develop a credible, modern and effective defense capability. The aim is to strengthen civilian control over the armed forces, in accordance with the principles and values of democracy, as well as to strengthen the Romanian status of security generator, by continuing and improving the contribution to regional stability.

Establishing coherent public policies in the field of national security provides stability and credibility both at the political level and among citizens. Thus, Romania's international strategic 
partners can be based on a behavior of our country in accordance with the values and principles specific to democracies, but also the observance of the norms of the rule of law.

Romania's objectives in NATO:

- Commitments on defense spending - has a special significance for demonstrating the credibility, unity and solidarity of the allies;

- Support for partners;

- Participation in measures to strengthen the advanced Allied presence on the eastern flank;

- Participation in missions and operations.

\section{CONCLUSIONS}

In conclusion, we can say that Romania has evolved quite a lot since 1990, fulfilling the main national objectives for the development and consolidation of the external position. Today, the security environment, both internal and external, is constantly changing, so for these new challenges, new solutions are essential, which correspond to the realities, and Romania is constantly improving this security strategy by being also in a geopolitical area of strategic interest.

Taking into account the information presented above, we conclude that Romania, as an EU member, benefits from certain advantages offered by it in the field of foreign affairs, as well as security. Also, in addition to the benefits it receives, our country also assumes responsibilities at the international level. These responsibilities will increase the importance of our state worldwide. Through compliance with foreign and security policies, Romania has affirmed its position as a trusted member, continuing its existing partnerships.

\section{REFERENCES}

The Presidential Administration of Romania (2020) The National Defence Strategy of the Country for the 2020-2024 timeframe, retrieved at 04 July 2021, available at: https://www.mapn.ro/ legislatie/documente/Strategia_Nationala_de_Aparare_a_Tarii_2020_2024.pdf

Acemoglu, D. (2008). The Form of Property Rights: Oligarchic vs. Democratic Societies, Journal of the European Economic Association, vol. 6, no. 1, 1-44.

Acemoglu, D., Johnson, S., Robinson, J. (2001). The Colonial Origins of Comparative Development: An Empirical Investigation, American Economic Review, vol. 9, no. 5, 13691401

Aristotle (1996). The Politics and the Consitution of Athens, New York City, NY: Cambridge University Press, New York

Bodislav, D. A. (2012). Oligarchy versus Democracy and Regulation versus Deregulation under the Globalization Effect, Theoretical and Applied Economics, vol. XIX, no. 5(570). 33-46.

Bodislav, D. A., Buzoianu, O. A. C., Burlacu, S., \& Rădulescu, C. V. (2020). Analysis of companies in Romania from the perspective of risk perception and the management needs thereof. Economic Convergence in European Union, 341.

Bran, F., Alpopi, C., \& Burlacu, S. (2018). Territorial Development-Disparities between the Developed and the least Developed Areas of Romania. LUMEN Proceedings, 6(1), 146-155.

Burlacu, S. (2011). Le rôle des ONG pour la prise de conscience de l'importance des partenariats publics-prives dans l'économie sociale en Roumanie. Administratie si Management Public «(RAMP), (17), 120-129.

Cairncross, F. (1997). The Death of Distance, New York City, NY: Orion House.

Carra, C., Burlacu, S., \& Faggianelli, D. (2018). Violence within the Organizations of Health and Medico-Social Sector. A Comparative Analysis of France and Romania. Economics, Management and Financial Markets, 13(3), 185-202. 
Georgescu, R. I. (2020). Strategii de valorificare a resurseloe naturale in contextul globalizarii, Bucharest, RO: Universitara Publishing.

Ioniţă, F., Burlacu, S., \& Gaidargi, A. (2009) Modern Approaches of the Management of Alternative Trade Systems, Revista de Management Comparat Internațional/Review of International Comparative Management, 51, 473-480

Jianu, I., Dobre, I., Bodislav, D. A., Radulescu, C. V., \& Burlacu, S. (2019). The Implications of Institutional Specificities on the Income Inequalities Drivers in European Union. Economic Computation and Economic Cybernetics Studies and Research, 53(2), 59-76.

Negescu, M. D., Burlacu, S., Mitriţă, M. Buzoianu, O C A. Managerial Analysis of Factoring at the International Level Challenges of the Contemporary Society. Proceedings; Cluj-Napoca Vol. 13, Iss. 1 : 99-102. Cluj-Napoca: Babes Bolyai University. (2020)

Peltzman, S. (1976). Toward a More General Theory of Regulation", Journal of Law and Economics, no. 19. 211-240.

Platon (1993). Republica, Bucharest, RO: Antet Publishing.

Pricop, L. C., Burlacu, S., \& Demeter, M. L. (2016). Managing Violence in Health Sector Through BI Solutions. In Proceedings of the International Management Conference (Vol. 10, No. 1, pp. 512-519). Faculty of Management, Academy of Economic Studies, Bucharest, Romania.

Rădulescu, C. V., Bodislav, D. A., Bran, F., \& Burlacu, S. (2020). The Impact Of Cross-Border Cooperation Between The Republic Of Moldova And Romania On Socio-Economic Development. EURINT, 7, 63-79.

Smith, A. (1994). An Inquiry Into the Nature and Causes of the Wealth of Nations, New York City, NY: Random House. 